\title{
Economic model for obtaining cyclodextrins from commercial cgtase
}

\author{
Luciana Numata Koga $\mathbf{1}$, Vanderson Carvalho Fenelon, Juliana \\ Harumi Miyoshi ${ }^{1}$, Cristiane Moriwaki ${ }^{1}$, Kamila Byanca BaldinWessel ${ }^{2}$, \\ Camila Sampaio Mangolim ${ }^{\underline{3}}$, Graciette Matioli ${ }^{\oplus 1^{*}}$
}

${ }^{1}$ Department of Pharmacy, State University of Maringá, Maringá, Paraná, Brazil, ${ }^{2}$ Postgraduate in Biotechnology, State University of Londrina, Londrina Brazil, ${ }^{3}$ Department of Management and Industrial Technology, Federal University of Paraiba, Paraiba, Brazil

\begin{abstract}
A repetitive batch process was employed followed by membrane ultrafiltration system to produce low-cost cyclodextrins (CDs) using commercial enzymes Toruzyme ${ }^{\circledR}$ cyclomaltodextrin glucanotransferase (CGTase) and its kinetic parameters were determined. The ultrafiltration system enabled the removalof inhibitory products from the reaction medium, allowing the enzyme to be recovered for reuse. A $10 \mathrm{kDa}$ membrane was used to separate the different CDs produced by the CGTase. The substrates evaluated were maltodextrin, corn starch and cassava starch at 5, 10 and 15\% $(\mathrm{w} / \mathrm{V})$, in the presence and absence of $10 \%(\mathrm{~V} / \mathrm{V})$ ethanol. After reaction for $132 \mathrm{~h}, 10 \%(\mathrm{w} / \mathrm{V})$ cassava starch in the presence of ethanol provided the best results with $32.1 \mathrm{mg} / \mathrm{mL}$ of $\beta-\mathrm{CD}$. Maximum production occurred after $72 \mathrm{~h}$ of reaction, with a yield of $87.4 \%$ of $\beta-\mathrm{CD}$ and an $\alpha-\mathrm{CD}, \beta-\mathrm{CD}$ and $\gamma$-CD production ratio of 1:1:0.08 g, respectively. When eight repetitive batches of $72 \mathrm{~h}$ followed by ultrafiltration and crystallization of $\beta$-CD were performed, $2.1 \mathrm{~g}$ of precipitate was obtained with a purity of $67.6 \% \beta-\mathrm{CD}$. The supernatant from the crystallization process was lyophilized and resulted in $35.3 \% \alpha-C D$. The developed model can be used industrially for the production of low cost CDs from easily obtained raw material.
\end{abstract}

Keywords: Cyclodextrin. Commercial CGTase. Ultrafiltration. Repetitive batches. Starch.

\section{INTRODUCTION}

Cyclodextrins (CDs) are cyclic oligosaccharides composed of glucose units connected by $\alpha-1,4-$ linked glycosidic bonds. The most commonly found are generally $\alpha-C D$ (cyclohexaamylose), $\beta-C D$ (cycloheptaamylose) and $\gamma$-CD (cyclooctaamylose), which consist of 6,7 and 8 glucose units, respectively. They have a truncated cone shape with an apolar central cavity and the capacity to encapsulate several molecules, modifying their physicochemical properties. The outer part is polar, which allows the solubilization of the

*Correspondence: G. Matioli. Universidade Estadual de Maringá. Departamento de Farmácia - Laboratório de Biotecnologia Enzimática. Av. Colombo 5790, BL P02; CEP: 87020-900 - Maringá-PR, Brasil. Phone: +55 44 30113868. E-mail: gmatioli@uem.br encapsulated apolar molecules (Szejtli, 1998). They can therefore be used to increase the solubility of the host molecule in water, reducing volatility, increasing the stability of the host molecule, and masking unpleasant flavors. These and other properties make CDs suitable for application in the pharmaceutical, food, textile and other industries(Slomińska, Szostek, Grześkowiak, 2002; Tiwari, Tiwari, Raia, 2010; Kurkov, Loftsson, 2013).

Cyclodextrins are produced by the action of the cyclomaltodextrin glucanotransferase enzyme (CGTase - EC 2.4.1.19), which uses starch as a substrate. They are formed by the reversible reactions of intramolecular transglycosylation, or cyclization. However, CGTase enzymes are also active in intermolecular transglycosylation reactions (coupling 
and disproportionation) and, to a lesser extent, in the hydrolysis reactions of starch (Han et al., 2014).

The enzyme commercially known as Toruzyme ${ }^{\circledR}$ is a CGTase solution derived from a Bacillus lineage that received the CGTase gene from a strain of Thermoanaerobacter sp., which is commercialized by Novozymes A/S (Krogshoejvej 362880 - Bagsvaerd Denmark). The CGTase of Thermoanaerobacter $\mathrm{sp}$ has significant starch hydrolysis capacity, is resistant to high temperatures, and produces similar quantities of $\alpha$ - and $\beta$-CDs and low amounts of $\gamma$-CD (Norman, Jorgensen, 1992).

Certain factors involved in the production process of CDs can limit the conversion of the substrate, such as the reaction products (linear maltodextrins and the concentration of formed CDs). Previous studies have aimed to minimize these factors, including through the ultrafiltration process (Fenelon et al., 2015; Caiming et al., 2016; Fenelon et al., 2018). CGTase, cassava starch and other oligosaccharides have a higher molar mass than CDs and when using a $10 \mathrm{kDa}$ membrane ultrafiltration system, for example, the molecules are retained while the three types of CDs are filtered, keeping the reaction medium free of inhibitors. In this way, the yield of CDs can be improved by the removal of the inhibitory products that accumulate in the reaction mixture.

Fenelon et al., 2018 evaluated different strategic models for CD production by the CGTase of Bacillus firmus strain 37. Some of these strategies used repetitive batches in ultrafiltration systems and all of them were efficient to separate CGTase from its inhibitory products and to enable its reuse, giving satisfactory $C D$ yield.

The use of ethanol in the production of CDs prevents hydrolytic reactions, as it excludes water molecules from the active center of the enzyme and also prevents reverse reactions, delaying the decomposition of the CDs formed. This additive can be easily evaporated and reused and also reduces the possibility of microbial contamination during the process.

Ethanol concentration above $20 \%$ may cause denaturation of the enzyme, inactivating it. The presence of ethanol is favorable when using high starch concentrations (Mattsson et al., 1991; Calsavara et al., 2011; Fenelon et al., 2015).

One example of the use of cassava substrate in the production of CDs is the state of Paraná, which is responsible for more than $65 \%$ of cassava starch production in Brazil, supplying the chemical, medicinal and food industries in the country (SEAB, 2018).
According to the Centro de Estudos Avançados em Economia Aplicada da Escola Superior de Agricultura "Luiz de Queiroz"(ESALQ/USP, 2018), cassava starch was quoted ashaving a price of around US\$ 640 a ton (approximately 41 cents by kilogram), in the second half of 2018. With regard to CDs, the prices for $1 \mathrm{~kg}$ of the $\alpha-, \beta$ - and $\gamma$-CDs, according to the Shandong Binzhou Zhiyuan Biotechnology Co., Ltd. (China), were U\$73, U\$9 and U\$260, respectively. Thus, the value of $\beta-C D$ is approximately 22 times greater than that of its source substrate.

Due to the great demand for CDs and their various applications, considerable research has been carried out to increase their production. The aim of the present study was to describe an economical model for the production of CDs by using an ultrafiltration system to remove the inhibitory factors formed in the reaction medium, as well as the use of repetitive batches to enable reuse of the commercial CGTase. In addition, the influence of ethanol on the reaction medium was evaluated, the kinetic parameters of the commercial enzyme (Toruzyme ${ }^{\circledR} 3.0 \mathrm{~L}$ ) were defined, and the produced $\beta$-CD was crystallized and its yield determined.

\section{MATERIALS AND METHODS}

\section{Materials}

The $\alpha-, \beta$ - and $\gamma$-CD standards were purchased from Sigma Aldrich (St. Louis, MO, USA). The substrates used were cassava starch (Polvilho Doce, Alimentos Zaeli LTDA, Brazil), corn starch (Cornna, Unilever Company LTDA, Brazil) and maltodextrin (Sigma Aldrich LTDA, Brazil). The 3.0L Toruzyme ${ }^{\circledR}$ enzyme was supplied by Novozymes (Bento Gonçalves, Rio Grande do Sul, Brazil). Other chemical reagents were of analytical grade.

\section{Determination of best enzyme concentration and quantification of CGTase protein}

The best enzyme concentration was determined using the initial velocity method (Dixon, Webb, 1979). The protein concentration of the enzyme was analyzed according to the Bradford method (Bradford, 1976). The reaction medium containing $15 \%(\mathrm{w} / \mathrm{V})$ maltodextrin diluted in $10 \%(\mathrm{~V} / \mathrm{V})$ of $10 \mathrm{mM}$ sodium citrate buffer $\mathrm{pH}$ 6.0 was prepared and placed in a $50 \mathrm{~mL}$ jacketed glass reactor and coupled in a bath thermostated at $65^{\circ} \mathrm{C}$ under 
constant magnetic stirring. The enzyme concentration was tested at $0.1 \%(\mathrm{~V} / \mathrm{V})$ and $0.02 \%(\mathrm{~V} / \mathrm{V})$, relative to the volume of reaction medium $(50 \mathrm{~mL})$, and $1 \mathrm{~mL}$ of the medium was collected at 5 min intervals, inactivated with $1 \mathrm{~mL}$ of $0.02 \mathrm{~N} \mathrm{HCl}$ and placed in a boiling bath for 5 $\mathrm{min}$. The reaction lasted $30 \mathrm{~min}$. The temperature, ethanol concentration and sodium citrate buffer used were defined according to the Calsavaraet al. (2011) methodology. The best dilution was chosen based on the coefficient of determination $\left(\mathrm{R}^{2}\right)$ of the concentration of $\beta-C D$ produced graph versus time, with this coefficient indicatingto what extent the model explains the observed values. A higher $\mathrm{R}^{2}$ value represents a more explanatory model which better fits the sample. The assays were performed in triplicate.

\section{Determination of best substrate for $C D$ production}

The influence of the type of substrate was determined in relation to enzymatic activity, with one unit of activity (U) corresponding to the amount of CGTase that produces $1 \mu \mathrm{mol}$ of $\mathrm{CD} / \mathrm{min}$ under the reaction conditions. The substrates used were corn starch, cassava starch and maltodextrin at concentrations of 5,10 and $15 \%(\mathrm{w} / \mathrm{V})$ diluted in $10 \%(\mathrm{~V} / \mathrm{V})$ of $10 \mathrm{mM}$ sodium citrate buffer $\mathrm{pH} 6.0$ and $0.02 \%$ of enzyme in 50 $\mathrm{mL}$ of reaction medium, at room temperature, all in the presence and absence of $10 \%(\mathrm{~V} / \mathrm{V})$ ethanol.

The reaction medium was placed in a jacketed glass reactor coupled to a thermostated bath at $65{ }^{\circ} \mathrm{C}$ under constant magnetic stirring. The enzyme was added by initiating the reaction and then $1 \mathrm{~mL}$ of the medium was collected, inactivated with $1 \mathrm{~mL}$ of $0.02 \mathrm{~N} \mathrm{HCl}$ in a centrifuge tube and boiled for $5 \mathrm{~min}$. A volume of 2 $\mathrm{mL}$ of distilled water was then added and centrifuged at $8,000 \mathrm{x} \mathrm{g}$ at $40{ }^{\circ} \mathrm{C}$ for $20 \mathrm{~min}$. The supernatant was separated for spectrophotometric analysis by the phenolphthalein method. The other samples were collected at $0,5,10,15,20,25,30$ and $60 \mathrm{~min}$ and the inactivation procedure described above was performed. The assays were performed in triplicat.

The activity calculation was performed according to equation 1 (Moriwaki et al., 2009).

$$
\mathrm{A}=\frac{\mathrm{K}^{\prime} \times \mathrm{V}_{\mathrm{R}} \times \mathrm{D}}{\mathrm{V}_{\mathrm{E}}}
$$

Where:

$\mathrm{K}^{\prime}=$ slope of the concentration line of $\mathrm{CDs}$ as a function of time ( $\min \mathrm{x} \mathrm{mmol} / \mathrm{L}$ )
$\mathrm{VR}=$ total volume of reaction (substrate volume + enzyme volume)

$\mathrm{D}=$ enzyme dilution

$\mathrm{VE}=$ volume of diluted enzyme

\section{Determination of substrate concentration, presence or absence of $10 \%$ ethanol (V/V) and duration of each batch for the production of the CDs}

The reaction medium containing $10 \%$ and $15 \%$ $(\mathrm{w} / \mathrm{V})$ cassava starch in the presence and absence of $10 \%(\mathrm{~V} / \mathrm{V})$ ethanol and $0.02 \%$ of enzyme in $50 \mathrm{~mL}$ of reaction medium was used as a substrate for the production of CDs. A volume of $1 \mathrm{~mL}$ of the reaction medium was collected at 1, 6, 12, 24, 48, 72, 84, 120 and $132 \mathrm{~h}$ and immediately inactivated as described above. The tubes were centrifuged at $12,000 \mathrm{xg}$, at $40{ }^{\circ} \mathrm{C}$ for 10 min. The supernatants were separated and analyzed by the phenolphthalein and chromatographic methods. The assays were performed in triplicate.

\section{Determination of kinetic parameters of CGTase}

\section{Activation Energy}

To determine the influence of temperature on the initial rate of $\beta-C D$ production, temperatures between 40 and $90{ }^{\circ} \mathrm{C}$ were selected. The experiments were performed using $10 \%(\mathrm{w} / \mathrm{V})$ cassava starch dissolved in $10 \%(\mathrm{~V} / \mathrm{V})$ of $10 \mathrm{mM}$ sodium citrate buffer $\mathrm{pH} 6.0$ as the substrate; and $10 \%(\mathrm{~V} / \mathrm{V})$ ethanol at temperatures of 40 , $50,60,70,80,90$ and $95^{\circ} \mathrm{C}$. The collected samples were centrifuged at $12,000 \mathrm{x} \mathrm{g}$, at $40{ }^{\circ} \mathrm{C}$ for $10 \mathrm{~min}$, and the supernatants were analyzed by the spectrophotometric method (Tardioli, Zanin, Moraes, 2006). The assays were performed in triplicate.

The Arrhenius equation described by por Moriwaki et al. (2007) allowed the activation energy of the enzyme to be determined.

\section{Inactivation energy and half-life time}

For this test, two thermostated baths were used, each coupled to a jacketed glass reactor (R1 and R2). One bath, to which the $\mathrm{R} 1$ reactor containing $50 \mathrm{~mL}$ of the reaction medium (10\% cassava starch and $10 \%$ ethanol) and 500 $\mu l$ of pure enzyme was coupled, was used to submit the enzyme to the different test temperatures $(70,75,80$, 85 and $90{ }^{\circ} \mathrm{C}$ ). Aliquots of $1 \mathrm{~mL}$ were collected after 
$0,40,80,120,160,200$ and 240 min of permanence in the reactor and transferred to the $\mathrm{R} 2$ reactor, which was coupled to another bath, and maintained at $65{ }^{\circ} \mathrm{C}$ with $10 \%$ cassava starch and 10\% ethanol. For the times in R1, the aliquots were tested in a new reaction medium in $\mathrm{R} 2$, and remained for $30 \mathrm{~min}$. At $5 \mathrm{~min}$ intervals $1 \mathrm{~mL}$ aliquots of $\mathrm{R} 2$ were drawn into centrifuge tubes containing $1 \mathrm{~mL}$ of $0.02 \mathrm{~N} \mathrm{HCl}$ and placed in the boiling bath for $5 \mathrm{~min}$ for inactivation of the enzyme. The samples were then cooled and $2 \mathrm{~mL}$ of distilled water was added and centrifuged at $12,000 \mathrm{x} \mathrm{g}$ at $40{ }^{\circ} \mathrm{C}$ for $10 \mathrm{~min}$. The supernatants were separated and analyzed by the spectrophotometric method (Tardioli, Zanin, Moraes, 2006).

The effect of temperature on CGTase stability is determined by the thermal denaturation of the enzyme, in which the reaction rate begins to decrease. It is determined by the coefficient of thermal inactivation $(\mathrm{Kd})$ given by the Arrhenius equation described by Matioli et al. (2001).

The half-life of the enzyme (t1/2) corresponds to the time in which the enzyme loses half its activity. It is related to enzymatic stability and is inversely proportional to the Kd value. The assays were performed in triplicate.

\section{Influence on variation of substrate concentration}

Inhibition of enzyme activity is influenced by the initial concentration of the substrate. The experiment was conducted under previously determined optimized conditions, but with cassava starch at concentrations of $0.05 ; 0.1 ; 0.25 ; 0.5 ; 0.75 ; 1 ; 1.5,2.5 ; 5 ; 7.5 ; 10$ and $17.5 \%(\mathrm{w} / \mathrm{V})$, in the presence of $10 \%(\mathrm{~V} / \mathrm{V})$ ethanol. The samples were centrifuged at $12,000 \mathrm{x}$ g at $40{ }^{\circ} \mathrm{C}$ for 10 min. The separated supernatants were analyzed by the spectrophotometric method. The assays were performed in triplicate. The calculation was determined by the Michaelis-Menten equation following the Haldane kinetic model (Segel, 1975), expressed in mol/L.

\section{Determination of the starch conversion rate in CGTase products}

A preliminary batch test followed by ultrafiltration was performed to determine the rate of conversion of the starch by the enzyme. The substrate used was $10 \%$ $(\mathrm{w} / \mathrm{V})$ cassava starch dissolved in $10 \%(\mathrm{~V} / \mathrm{V}) 10 \mathrm{mM}$ sodium citrate buffer $\mathrm{pH} 6.0$ and $10 \%(\mathrm{~V} / \mathrm{V})$ ethanol. The medium was transferred to a jacketed glass reactor with $50 \mathrm{~mL}$ capacity, coupled to a thermostated bath at $65{ }^{\circ} \mathrm{C}$, and to a condenser to prevent the loss of ethanol. The magnetic agitation was constant for $72 \mathrm{~h}$. After this time, $1 \mathrm{~mL}$ of the medium was collected for the determination of the CDs produced. The remaining medium was transferred to the Amicon ${ }^{\circledR}$ ultrafiltration device, consisting of a $10 \mathrm{kDa}, 44.5 \mathrm{~mm}$ diameter membrane. Ultrafiltration occurred under nitrogen gas pressure at $300 \mathrm{kPa}$ and constant agitation. The $\alpha-, \beta-$ and $\gamma$-CDs, which have a molar mass of $972 \mathrm{Da}, 1135$ Da and $1297 \mathrm{Da}$, respectively, were filtered during the process, whereas the CGTase with an estimated molar mass of 59 to $110 \mathrm{kDa}$ was retained (Ibrahim et al., 2012).

The ultrafiltrate and the retained medium, together with the sample collected at the end of $72 \mathrm{~h}$, were analyzed spectrophotometrically for the production of $\beta-C D$, and with the retained medium the total sugars were determined by the sulfuric phenol method (Dubois et al., 1956), which defined the starch conversion rate. The assay was performed in triplicate.

\section{Repetitive batching with 10 kDa membrane ultrafiltration}

The repetitive batch process was initiated following the methodology described above for the starch conversion rate. The medium retained in the device was resuspended in cassava starch solution $(1.75 \mathrm{~g} / 40 \mathrm{~mL})$ calculated by the conversion rateand $5 \mathrm{~mL}$ of ethanol. At each cycle the ultrafiltrate was collected and stored at $4{ }^{\circ} \mathrm{C}$ for further spectrophotometric and chromatographic analyzes. The cycles were repeated until a constant concentration of the formed CDs was observed. The assays were performed in triplicate.

\section{Crystallization of the $\beta-C D$ formed in the repetitive batch}

The $\beta$-CD produced was purified by crystallization, following the methodology described by Moriwaki et al. (2014). After crystallization, the supernatant was subjected to lyophilization at $-50{ }^{\circ} \mathrm{C}$ for $48 \mathrm{~h}$ and the precipitate was dried in an oven at $60^{\circ} \mathrm{C}$ for $36 \mathrm{~h}$ and $80^{\circ} \mathrm{C}$ for $12 \mathrm{~h}$. The powders from the crystallization and lyophilization were crushed in a mortar and placed in an oven at $65{ }^{\circ} \mathrm{C}$ until a constant weight was obtained, resuspended and analyzed by chromatography.

To determine the water content of the crystallized $\beta$-CD the Karl Fischer automatic titrator was used in 
accordance with the methodology of the Farmacopéia Brasileira (Brazilian Pharmacopoeia) (ANVISA, 2010).

\section{Separation of CDs by $1 \mathrm{kDa}$ membrane ultrafiltration, crystallization and recrystallization}

A new CD production assay was performed to preseparate $\alpha$-CD from the other CDs using $1 \mathrm{kDa}$ membrane ultrafiltration prior to the crystallization step. In the same assay the effectiveness of the recrystallization of the obtained samples was evaluated. Thus, the entire volume obtained from ultrafiltration in the $10 \mathrm{kDa}$ membrane was again subjected to the ultrafiltration process, but with a $1 \mathrm{kDa}$ membrane. The ultrafiltered contents were lyophilized and the contents retained in the device were subjected to crystallization. Recrystallization, in turn, was performed by resuspension of samples from the crystallization and lyophilization process. Dilution was calculated according to the solubility of $\beta-C D$. The samples were analyzed by high performance liquid chromatography (HPLC).

\section{Analytical methods}

The protein concentration of CGTase was analyzed according to the Bradford methodology (Bradford, 1976).

In accordance with the Complexity Theory (Tardioli, Zanin, Moraes, 2006), $\beta-\mathrm{CD}$ (mM) concentration was measured by discoloration of a phenolphthalein solution analyzed by a spectrophotometer at $550 \mathrm{~nm}$, which occurs after complexation with $\beta$-CD. The methodology applied is described by Moriwaki et al. (2009).

To determine the concentration of $\alpha-\beta$ - and $\gamma-C D$, the High Performance Liquid Chromatography (HPLC) method was used, according to Fenelon et al. (2015), but with a water and acetonitrile ratio of 45:55 and flow at $0.6 \mathrm{~mL} / \mathrm{min}$. The $\mathrm{CD}$ concentrations in the samples were calculated based on the ratio between the mean of the sample area and the mean of the area of each standard. One enzyme activity unit (U) corresponds to the amount of CGTase that produces $1 \mu \mathrm{mol}$ of $\mathrm{CD} / \mathrm{min}$ under the reaction conditions.

\section{Statistical Analysis}

The results of $\mathrm{CD}$ production were calculated by analysis of variance (ANOVA) and the means were compared by the Tukey test with a significance level of $5 \%$.

\section{RESULTS AND DISCUSSION}

\section{Influence of enzyme concentration on initial reaction rate and CGTase protein determination}

In order to verify the influence of commercial CGTase concentration on $\mathrm{CD}$ production, the initial velocity methodology was applied and the enzyme was evaluated at dilutions of $0.1 \%(\mathrm{~V} / \mathrm{V})$ and $0.02 \%$ $(\mathrm{V} / \mathrm{V})$. It was observed that the concentration of $\beta-\mathrm{CD}$ as a function of the reaction time in minutes resulted in good correlation between the points. The lines relating to the dilutions of the $0.1 \%$ and $0.02 \%(\mathrm{~V} / \mathrm{V})$ enzyme was adjusted by linear regression between the $\beta-C D$ concentration and the reaction time and enabled the determination of enzymatic activity, resulting in 372 and $556 \mathrm{U} / \mathrm{mL}$ and specific activity of 113 and 170 $\mathrm{U} / \mathrm{mg}$, respectively. The determination coefficients of the curves were very similar for both enzyme concentrations.The concentration of the enzyme $0.1 \%(\mathrm{~V} / \mathrm{V})$ did not make the yield proportional to the concentration of $0.02 \%(\mathrm{~V} / \mathrm{V})$, as the use of a five times greater volume of enzyme did not result in a fivefold increase in CDs. Therefore, the best dilution used in the assays of the present study was $0.02 \%(\mathrm{~V} / \mathrm{V})$. This result is significant, as due to its high cost a reduction in enzyme volume may be advantageous. The Toruzyme ${ }^{\mathbb{R}}$ enzyme is currently sold in a minimum quantity of 25 $\mathrm{kg}$ for US\$2,282.57.

When Calsavaraet al. (2011) used the same enzyme at concentrations of $0.05 ; 0.1 \%$ and $0.2 \%(\mathrm{~V} / \mathrm{V})$, with $15 \%(\mathrm{w} / \mathrm{V})$ corn starch as substrate and $15 \%(\mathrm{~V} / \mathrm{V})$ ethanol in the reaction medium, the best results were obtained at $0.1 \%(\mathrm{~V} / \mathrm{V})$ of enzyme, whereas lower concentration were unfavorable as they did not reduce the viscosity of the medium.

\section{Determination of the best substrate in the presence and absence of $10 \%$ ethanol (V/V)}

Among the substrates and concentrations tested, cassava starch provided better results than corn starch and maltodextrin, as observed in Figure 1. In terms of the percentage of substrate used, the concentrations of 10 and $15 \%$ stood out. A proportion of $10 \%(\mathrm{w} / \mathrm{V})$ cassava starch in both the presence and absence of ethanol resulted inenzymatic activity of 264 and $308 \mathrm{U} / \mathrm{mL}$, and specific activity of 80.7 and $94.2 \mathrm{U} / \mathrm{mg}$, respectively. When cassava starch was used at $15 \%(\mathrm{w} / \mathrm{V})$, in the presence and 
absence of ethanol, it resulted in an enzymatic activity of 248 and $304 \mathrm{U} / \mathrm{mL}$ and a specific activity of 75.8 and 93.0 $\mathrm{U} / \mathrm{mg}$, respectively. Therefore, no statistically significant difference in $\beta$-CD production was observed when using these two substrate concentrations.

Cassava starch, which as described above has the highest amount of amylopectin, was the most effective substrate at the concentrations tested, which may be due to differences in the structure of the starch granules and the properties of CGTase, resulting from various microorganisms. Grüll and Stifter (2001) recommended high amylopectin starches, explaining that these are more stable than amylose as the reaction with CGTase starts at the non-reducing end of the starch molecule. Amylopectin has more non-reducing end points than amylose, resulting in greater conversion to CGTase products.

As shown in Figure 1, for all substrates and concentrations tested, the presence of ethanol negatively influenced $\beta$-CD production during $60 \mathrm{~min}$ of reaction. This fact can be interpreted as a result of the short period of reaction. Initially, the interaction of ethanol with CGTase may be detrimental due to conformational changes, for example (Mattsson et al., 1991). However, in longer periods, when the equilibrium of the reaction is reached, ethanol's ability to avoid hydrolytic reactions that lead to the breakdown of $\mathrm{CD}$ molecules, causes the initial detriment to be overcome, increasing B-CD yield.

A $132 \mathrm{~h}$ reaction test was therefore performed, and the conditions chosen for the production of CDs were 10 and $15 \%(\mathrm{~V} / \mathrm{V})$ cassava starch in the presence and absence of ethanol. It is worth mentioning that Mattsson et al. (1991) reported that the effect of ethanol is more pronounced for higher starch concentrations; however, for concentrations of ethanol above $20 \%$ an abrupt decrease in $\mathrm{CD}$ yield was found, possibly due to the inhibition of the enzyme.

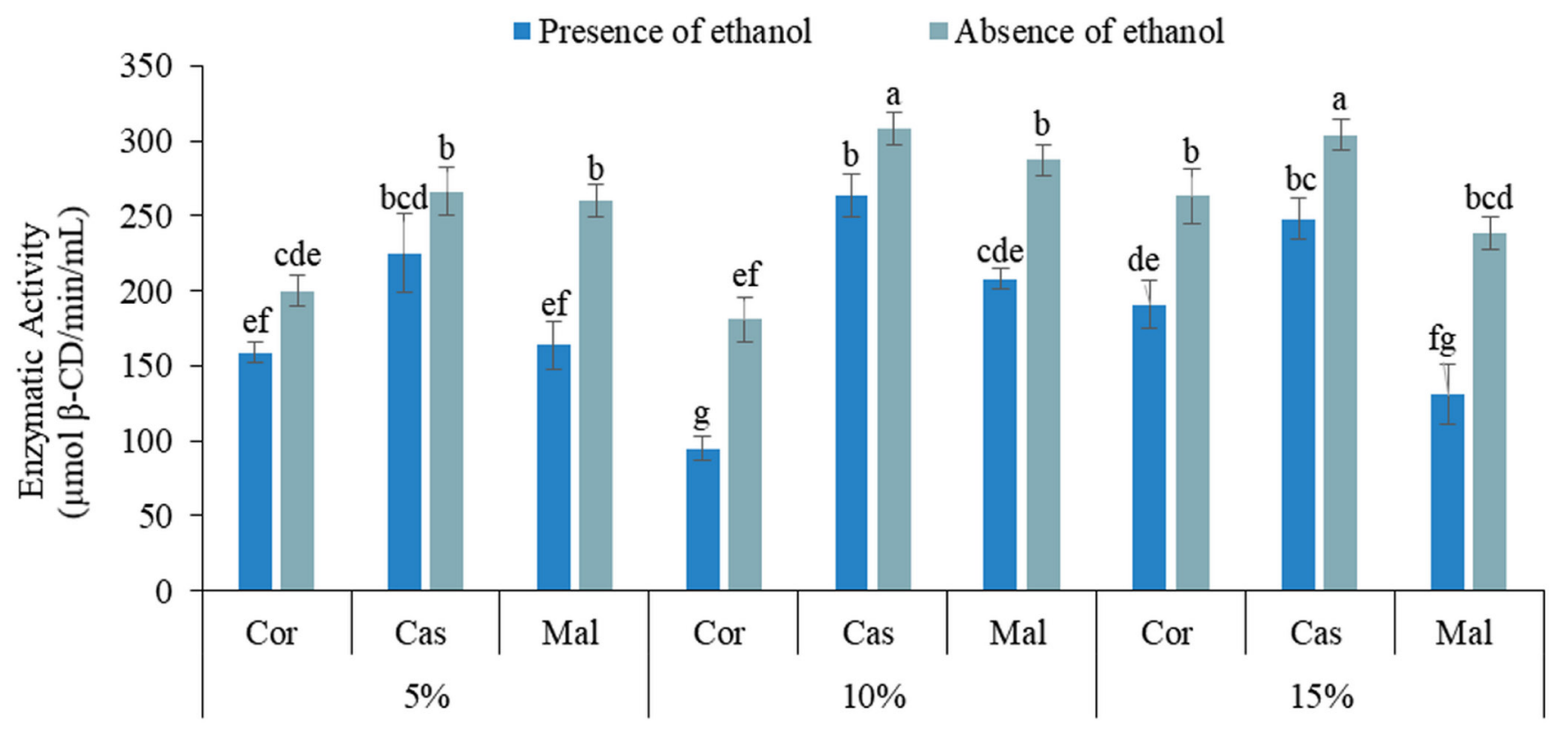

Substrate Concentration

FIGURE 1 - Determination of most effective substrate and the influence of ethanol on $\beta$-CD production using corn starch (Cor), cassava starch (Cas) and maltodextrin (Mal) at concentrations of 5, 10 and $15 \%(\mathrm{w} / \mathrm{V})$ in $10 \%(\mathrm{~V} / \mathrm{V}) 10 \mathrm{mM}$ sodium citrate buffer $\mathrm{pH} 6.0$, in the presence and absence of $10 \%$ ethanol $(\mathrm{V} / \mathrm{V})$ and $0.02 \%$ enzyme $(\mathrm{V} / \mathrm{V})$. The reaction lasted $60 \mathrm{~min}$ at 65 ${ }^{\circ} \mathrm{C}$. Spectrophotometric data were obtained for the $\beta$-CD dosages by the phenolphthalein method. 


\section{Determination of substrate concentration, the presence or absence of ethanol, and the duration of the production cycle of the CDs}

To determine the best substrate concentration, a $132 \mathrm{~h}$ cassava starch assay with and without the presence of ethanol was performed (Figure 2). Cassava starch at 10 and $15 \%(\mathrm{w} / \mathrm{v})$ in the presence of $10 \%$ ethanol $(\mathrm{V} / \mathrm{V})$ resulted in a yield of $32.12 \mathrm{mg} / \mathrm{mL}$ and $42.24 \mathrm{mg} / \mathrm{mL}$ of $\beta-C D$, respectively.

This assay determined the concentration of the substrate, which proved to be more viable when using $10 \%(\mathrm{w} / \mathrm{V})$ cassava starch in the presence of ethanol, as the addition of $50 \%$ of the substrate provided only a $24 \%$ increase of $\beta-\mathrm{CD}$. Therefore, the substrate concentration chosen for the repetitive batch process and ultrafiltration was $10 \%(\mathrm{w} / \mathrm{V})$ cassava starch in the presence of $10 \%$ $(\mathrm{V} / \mathrm{V})$ ethanol.

Figure 3 shows the results of the production of CDs at $132 \mathrm{~h}$ determined by chromatography with $10 \%$ $(\mathrm{w} / \mathrm{V})$ cassava starch in the presence of $10 \%(\mathrm{~V} / \mathrm{V})$ ethanol. Maximum $\beta$-CD production was reached at $120 \mathrm{~h}$, as occurred in spectrophotometric analysis by the phenolphthalein method (Figure 2).
The time set for each repetitive batch was $72 \mathrm{~h}$ as at this time the production of $\beta-\mathrm{CD}$ achieved a yield of $87.4 \%$ in relation to the maximum production of this $\mathrm{CD}$, which occurred in $120 \mathrm{~h}$. From $72 \mathrm{~h}$ onwards, increments of $12 \mathrm{~h}$ of production led to relatively insignificant increases in the production of $\beta-\mathrm{CD}$ of 4.0 ; $5.3 ; 1.5$ and $1.8 \%$, at $84,96,108$ and $120 \mathrm{~h}$, respectively. It was also observed that at $72 \mathrm{~h}$ the ratio of $\alpha, \beta$ and $\gamma$-CD formed was 1: 1: $0.08 \mathrm{~g}$, respectively, and that from this time onwards a stabilization of $\alpha-C D$ production occurred along with an increase in $\beta$-CD production. Therefore, the total of CDs formed in this period was $96.9 \%$, in relation to the maximum concentration of total CDs, reached in $108 \mathrm{~h}$, of which $45.6 \%$ was $\alpha-\mathrm{CD}$, $47.2 \% \beta-\mathrm{CD}$ and $4.1 \% \gamma-\mathrm{CD}$. The specific activity of the enzyme in the production of $\alpha, \beta$ and $\gamma$-CD resulted in 106.6; 39.6 and $26.9 \mathrm{U} / \mathrm{mg}$, respectively. Considering that the use of $10 \mu \mathrm{l}$ of enzyme in $50 \mathrm{~mL}$ of reaction medium provided a concentration of $47 \mathrm{mg} / \mathrm{mL}$ of CDs at the end of $132 \mathrm{~h}$, it was concluded that under these conditions the total yield of CDs was $234,4 \mathrm{~g}$ of the CDs per mL of enzyme.

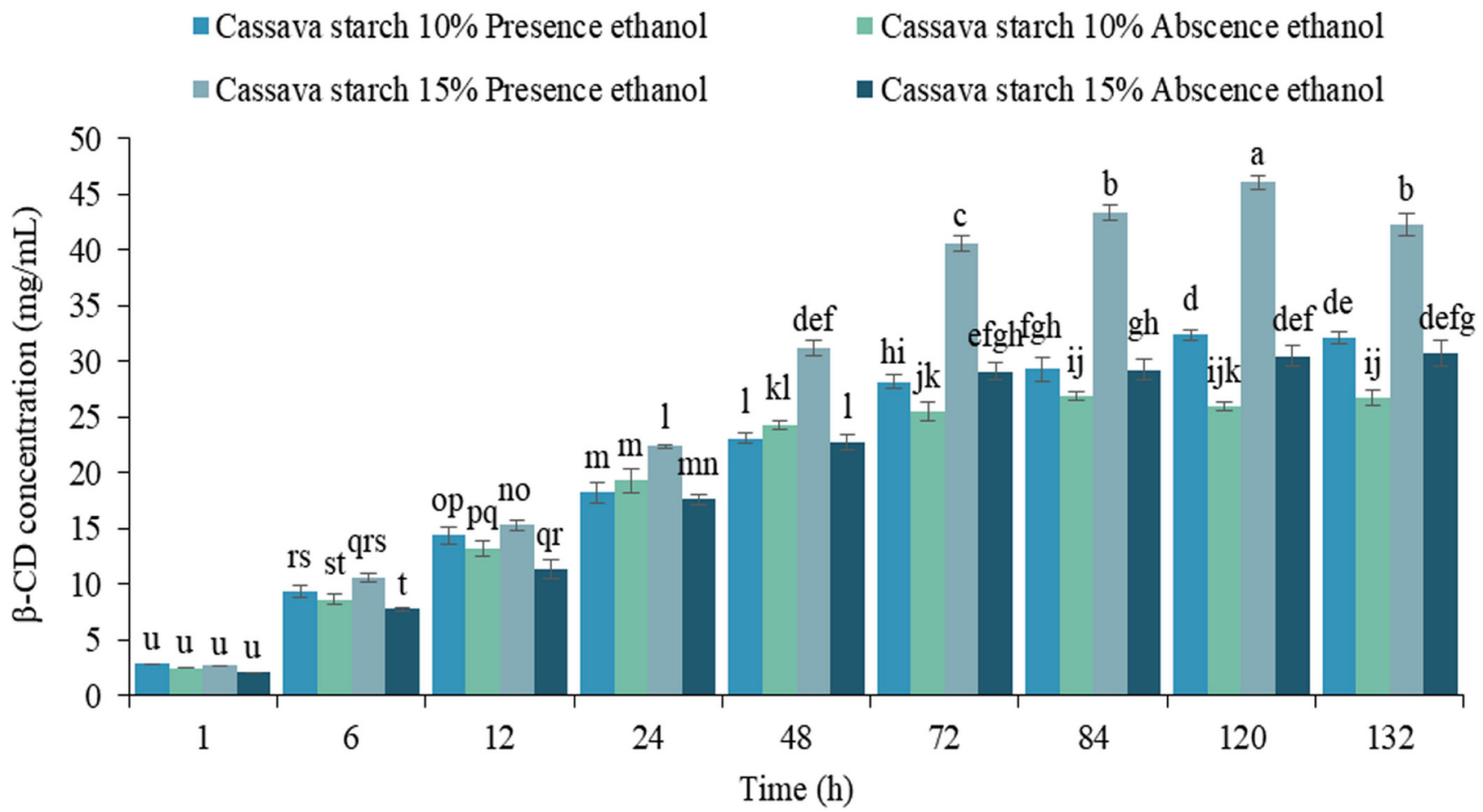

FIGURE 2 - $\beta$-CD production using 10 and $15 \%$ cassava starch $(\mathrm{w} / \mathrm{V})$ in the presence and absence of $10 \%$ ethanol (V/V) for 132 h. Spectrophotometric analysis using the phenolphthalein method. 


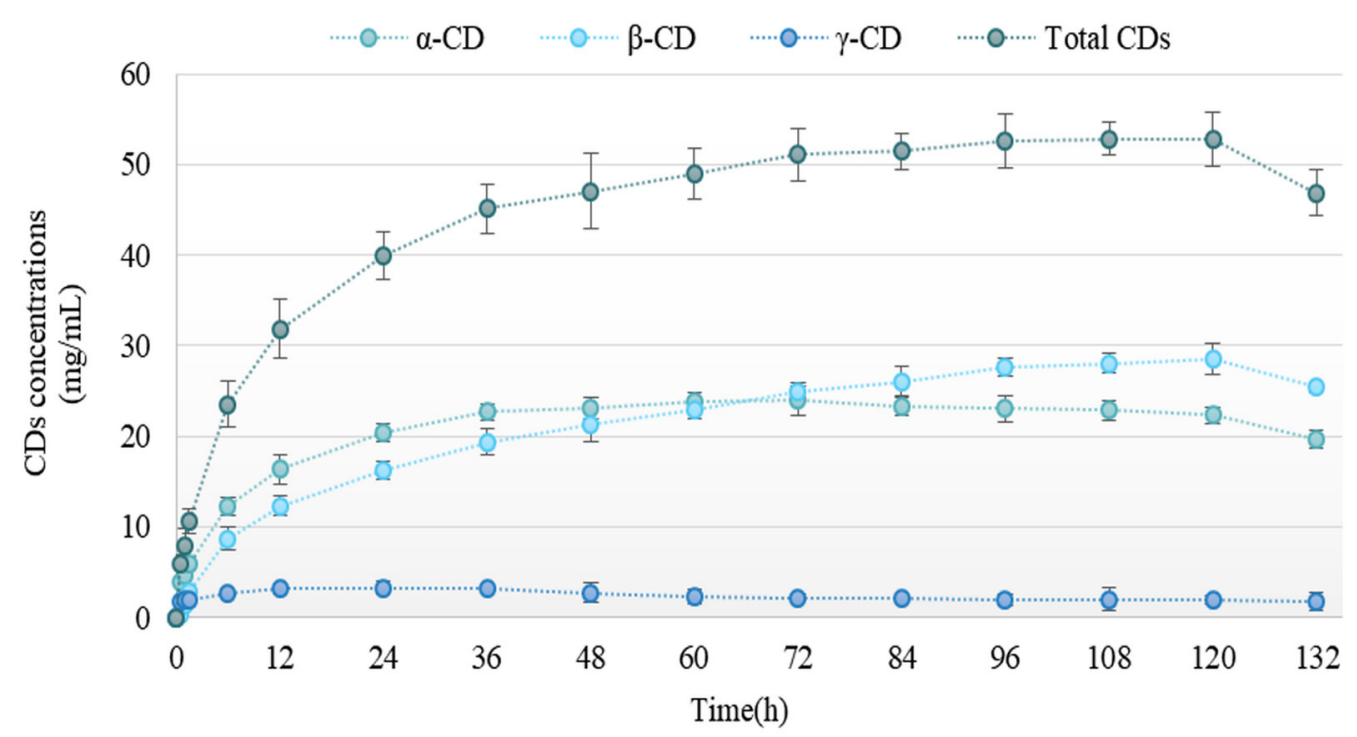

FIGURE 3 - Production of cyclodextrins over $132 \mathrm{~h}$ at $65^{\circ} \mathrm{C}$ using $10 \%(\mathrm{w} / \mathrm{V})$ cassava starch and $10 \%(\mathrm{~V} / \mathrm{V})$ ethanol as determined by chromatography.

Calsavara et al. (2011)found that $15 \%(\mathrm{w} / \mathrm{V})$ corn starch, in the presence of $10 \%(\mathrm{~V} / \mathrm{V})$ ethanol, $0.1 \%(\mathrm{~V} / \mathrm{V})$ Toruzyme ${ }^{\circledR}$ enzyme in $100 \mathrm{~mL}$ of reaction medium and a reaction time of $12 \mathrm{~h}$ obtained $37 \%$ of the total CDs formed, of which $52.2 \%$ were $\alpha-\mathrm{CD}, 38.8 \% \beta-\mathrm{CD}$ and $9.0 \% \gamma$-CD. The specific activity of the enzyme when producing $\alpha, \beta$ and $\gamma$-CD resulted in $37.25 ; 19.61$ and $8.63 \mathrm{U} / \mathrm{mg}$, respectively. The total yield of CDs per milliliter of enzyme was $55 \mathrm{~g}$.

\section{Kinetic parameters}

\section{Effect of temperature on enzymatic activity}

The maximum enzyme activity of $166 \mathrm{U} / \mathrm{mL}$ was reached at $70^{\circ} \mathrm{C}$. At temperatures above $70^{\circ} \mathrm{C}$ the activity of the enzyme remained practically constant (Figure 4a). This result is important, as high temperatures avoid microbial contaminations, and thermostable enzymes are of great industrial interest for various biotechnological applications. Moreover, higher temperatures favor the solubility of substrates and products, the reduction of viscosity and an increased diffusion coefficient of the substrates(Gomes et al., 2007).

The effect of the temperature on enzymatic activity was calculated by the Arrhenius equation, through adjustment to the experimental data. This adjustment allowed the determination of the activation energy
$\left(E_{\mathrm{a}}\right)$ which was $18.85 \mathrm{kcal} / \mathrm{mol}$ for the production of $\beta$-CD. Muria, Cheirsilp, Kitcha (2011) used CGTase from the Bacillus sp strain 26, sago starch as substrate, and temperatures from 45 to $70{ }^{\circ} \mathrm{C}$, and obtained an $\mathrm{E}_{\mathrm{a}}$ of $5,152 \mathrm{kcal} / \mathrm{mol}$. Abdel-Naby, Fouada, Reyadb (2015)found that the optimum CGTase temperature of Bacillus amyloliquefaciens was $58{ }^{\circ} \mathrm{C}$ and the $\mathrm{E}_{\mathrm{a}}$ was $3.92 \mathrm{kcal} / \mathrm{mol}$. Other authors used CGTase of Thermoanaerobacter sp and obtained an optimum reaction temperature of $100{ }^{\circ} \mathrm{C}$ (Matte et al., 2012; Zhou et al., 2010). Unsworth, Oost, Koutsopoulos (2007) achieved optimum reaction temperatures above $100{ }^{\circ} \mathrm{C}$ using other thermophilic enzymes.

With regard to thermal stability, the lowest thermal inactivation was found at a temperature of $70{ }^{\circ} \mathrm{C}$, and therefore longer reaction periods can be used at this temperature. When this temperature was compared with temperatures of $75,80,85$ and $90{ }^{\circ} \mathrm{C}$, a decrease in activity of 7, 78, 85 and 94\%, respectively (Figure 4b), was observed. An abrupt drop in activity was noted at temperatures of 75 to $80{ }^{\circ} \mathrm{C}$, meaning that the enzyme initiated the process of denaturation caused by temperature. While an increase in temperature increases the chemical reactions between enzyme and substrate, however, denaturation of the enzyme and, consequently, the interruption of the catalytic reaction, occurs if the temperature is too high (Rakmai, Cheirsilp, Prasertsan, 2015). Norman and Jorgensen (1992) reported that 
CGTase of Thermoanaerobacter are extremely thermostable and can reach an optimal temperature of 90 to $95^{\circ} \mathrm{C}$ at $\mathrm{pH} 6.0$.

The thermal inactivation energy was determined from the values of the thermal inactivation coefficient $(\mathrm{Kd})$, according to the Arrhenius equation, resulting in 19.30 $\mathrm{kcal} / \mathrm{mol}$. At temperatures of 80,85 and $90{ }^{\circ} \mathrm{C}$, the halflife was approximately 171,111 and $80 \mathrm{~min}$, respectively. Moriwaki et al. (2007) used CGTase of the Bacillus firmus strain 7B, 10\% (w/v) maltodextrin as substrate and $\mathrm{pH} 8$ at temperatures of 35 to $85{ }^{\circ} \mathrm{C}$ and obtained an $\mathrm{E}_{\mathrm{d}}$ of 37.8 $\mathrm{kcal} / \mathrm{mol}$. The half-life time was over $20 \mathrm{~h}$ for temperatures lower than $60^{\circ} \mathrm{C}$ and reduced to $30 \mathrm{~min}$ at $80^{\circ} \mathrm{C}$.

According to the results obtained, the thermal stability of the enzyme under study was considered satisfactory, taking into account the resistance of the enzyme, which is advantageous for the industrial production of CDs.

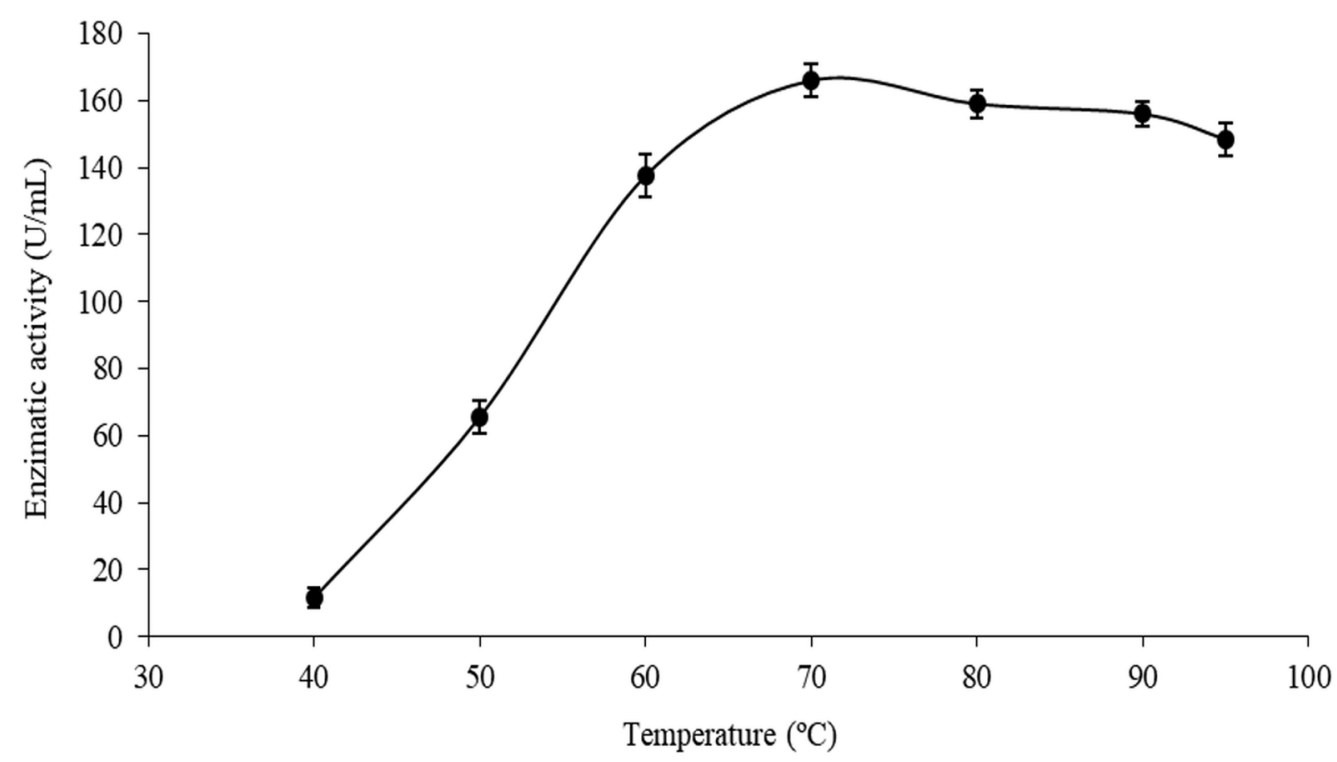

FIGURE 4A - Enzymatic activity in the production of $\beta$-CD as a function of temperatures of 40 to $95{ }^{\circ} \mathrm{C}$ using $10 \%(\mathrm{w} / \mathrm{V})$ cassava starch in the presence of $10 \%(\mathrm{~V} / \mathrm{V})$ ethanol.

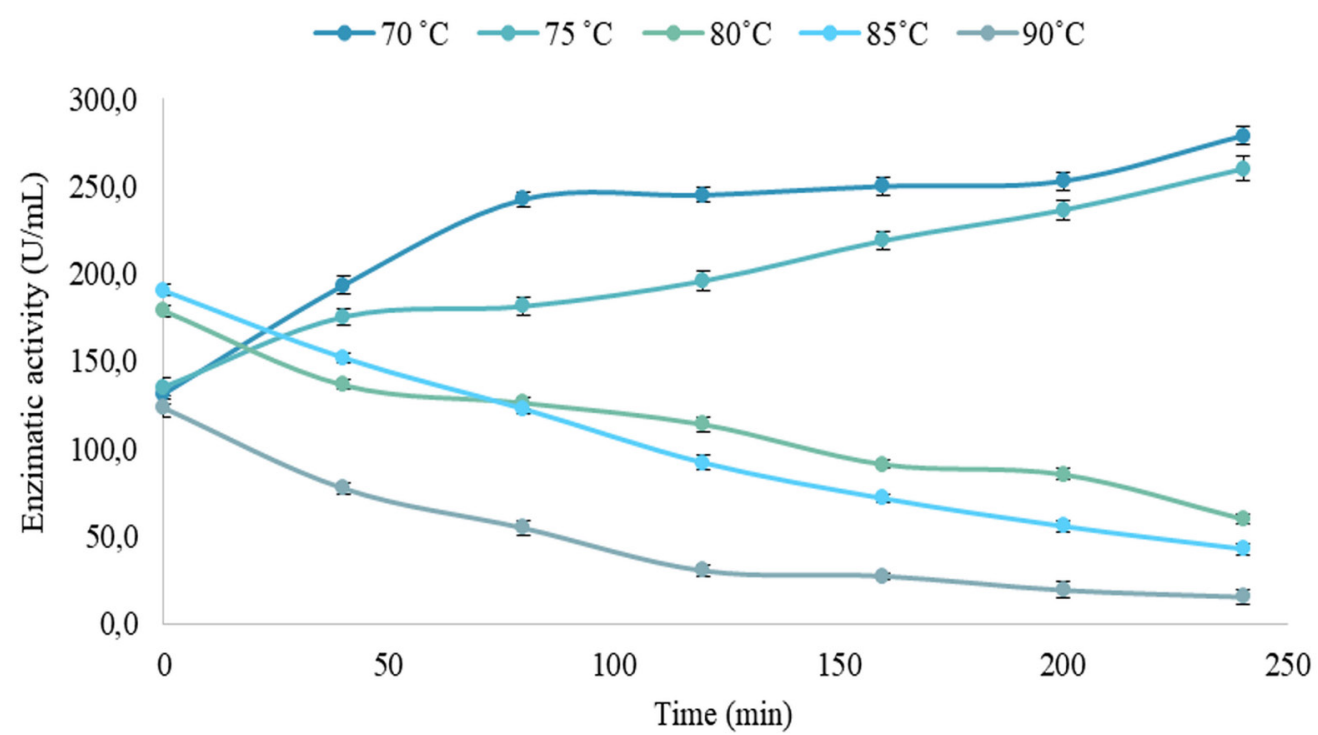

FIGURE 4B - Thermal stability in the production of $\beta$-CD at temperatures of 70 to $90{ }^{\circ} \mathrm{C}$. Conditions: $10 \%(\mathrm{w} / \mathrm{V})$ cassava starch and $0.02 \%(\mathrm{~V} / \mathrm{V})$ enzyme. 


\section{Influence of substrate concentration on CGTase activity}

Figure 5 shows the initial reaction rate (V) as a function of substrate concentration at $65^{\circ} \mathrm{C}$. Inhibition by the substrate was identified by the increase in the rate of $\beta-C D$ production with increasing substrate concentration up to $0.0005 \mathrm{~mol} / \mathrm{L}$, although this effectively stabilized with higher substrate concentration values. The Michaelis-Menten constant $\left(\mathrm{K}_{\mathrm{m}}\right)$ obtained for the cassava starch substrate under optimum conditions was $0.0011 \mathrm{~mol} / \mathrm{L}$ and the maximum velocity $\left(\mathrm{V}_{\max }\right)$ was $26.05 \mathrm{~mol}$ of $\beta-\mathrm{CD} / \mathrm{L} / \mathrm{h}$. Low $\mathrm{Km}$ values are related to higher substrate affinity. There is no absolute Vmax value for each enzyme, with the level depending on the amount of enzyme used (Pinheiro et al., 2017).

Matte et al.(2012) used soluble starch and Toruzyme $^{\circledR}$ and obtained $0.024 \mathrm{~mol} / \mathrm{L}$ of $\mathrm{K}_{\mathrm{m}}$ and 10.02 $\mathrm{mol} / \mathrm{L} / \mathrm{h}$ of $\mathrm{V}_{\max }$. Bonilha et al. (2006) obtained $\mathrm{K}_{\mathrm{m}}$ values of $0.00156 \mathrm{~mol} / \mathrm{L}$ and $\mathrm{V}_{\max } 19.87 \mathrm{~mol} / \mathrm{L} / \mathrm{h}$ of protein, with potato starch as a substrate and CGTase of $B$. licheniformis, of which the CGTase used in this experiment was genetically modified with this species of bacteria.

The $\mathrm{K}_{\mathrm{m}}$ value found for the enzyme studied was therefore considered satisfactory, or in other words, the enzyme had a high affinity for the cassava starch substrate.

\section{Determination of the starch conversion rate in CGTase products}

The CDs production process can be negatively influenced by some factors, such as a low yield which does not normally exceed $25 \%$ of substrate conversion in CDs (Pishtiyski, Zhekova, 2006). The increase in substrate concentration causes an increase in the volumetric productivity of the reactor as it increases $\beta$-CD concentration but also reduces the conversion of the starch to CDs. The low yield at high starch concentrations is due to the inhibition of the enzyme by the formation of CDs. Removal of the CDs by ultrafiltration increases yield (Fenelon et al., 2015). This assay was therefore carried out to promote a higher starch to CDs conversion rate through optimum reaction conditions, with a batch of $72 \mathrm{~h}$ followed by ultrafiltration.

The total amount of cassava starch present in the $50 \mathrm{~mL}$ reaction medium was $5 \mathrm{~g}$, of which $1.75 \mathrm{~g}$ were converted to linear CDs and oligosaccharides, which were separated by $10 \mathrm{kDa}$ membrane ultrafiltration. This represented a starch conversion rate of $35 \%$. The amount of starch remaining in the ultrafiltration process was obtained by determining the total sugars by the sulfuric phenol method, and corresponded to $3.25 \mathrm{~g}$.

Kim et al. (1997)produced CDs using Toruzyme ${ }^{\circledR}$ enzyme and $7.5 \%(\mathrm{w} / \mathrm{V})$ corn starch, $65{ }^{\circ} \mathrm{C}, \mathrm{pH} 6$ and $22 \mathrm{U} / \mathrm{g}$ of enzyme for $24 \mathrm{~h}$. The conversion of the

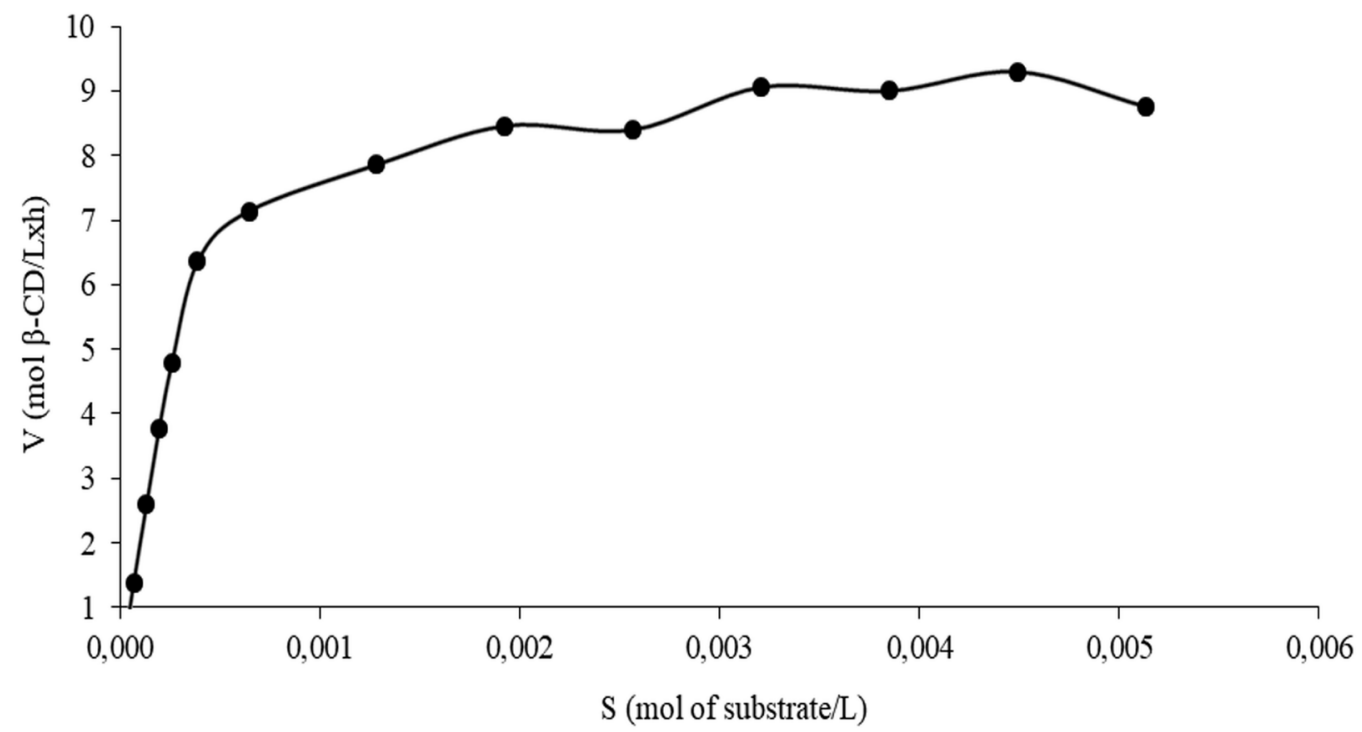

FIGURE 5 - Initial velocity of $\beta$-CD production by CGTase as a function of substrate concentration (S) with cassava starch, 10\% $(\mathrm{V} / \mathrm{V})$ ethanol at $65^{\circ} \mathrm{C}$. 
substrate to CDs was $27.9 \%$. Fenelon et al. (2015) using $5 \%(\mathrm{w} / \mathrm{V})$ corn starch with $10 \%(\mathrm{~V} / \mathrm{V})$ ethanol and $4 \%$ (V/V) semi-purified enzyme of Bacillus firmus strain 37 in a 12 height batch process followed by ultrafiltration, obtained a starch to CDs conversion rate of $26 \%$.

\section{Repetitive batching and ultrafiltration}

The purification of CDs often requires the use of organic solvents which can cause environmental hazards, toxicity, flammability and other disadvantages, limiting their use in the food and pharmaceutical industries (Caiming et al., 2016; Moriwaki et al., 2014). Ultrafiltration was used in this research, constituting, besides a tool that allows the reuse of the enzyme, a previous form of CDs separation that facilitates its further purification.

Figure 6 shows the eight repetitive batches with periods of $72 \mathrm{~h}$, followed by ultrafiltration. In the first batch there was a maximum production of $\alpha-, \beta$ - and $\gamma$-CD of $24.75 \mathrm{mmol} \mathrm{L}^{-1}, 20.59 \mathrm{mmol}^{\mathrm{L}-1}$ and $1.66 \mathrm{mmol}$ $\mathrm{L}^{-1}$, respectively. The last batch exhibited $13.51 \mathrm{mmol} \mathrm{L}^{-1}$ of $\alpha-C D$ and $7.96 \mathrm{mmol} \mathrm{L}^{-1}$ of $\beta-\mathrm{CD}$. With the exception of the first batch, no $\gamma-\mathrm{CD}$ production was detected throughout the experiment.

From the first to the second batch there was a reduction of 38 and $50 \%$ of the production of the $\alpha-C D s$ and $\beta$-CDs, respectively. From the second to the third batch there was a reduction of approximately $8 \%$ in both $\alpha-C D$ and $\beta-C D$, although from this point onwards production remained constant (means of $13.37 \mathrm{mmol} \mathrm{L}^{-1}$ of $\alpha-C D$ and $7.92 \mathrm{mmol} \mathrm{L}^{-1}$ of $\beta-C D$ ) until the last batch. In the last batch, $59 \%$ of the total CDs produced were $\alpha-C D$ and $41 \%$ were $\beta-C D$. No difficulty was observed in flow during ultrafiltration, with elimination of most of the inhibitory products produced by CGTase, and recovery of the enzyme and substrate which were not converted by the enzyme also possible. The enzyme in this experiment also converted $35 \%$ starch, calculated by the starch conversion rate using the sulfuric phenol method.

Calsavara et al. (2011) performed a $12 \mathrm{~h}$ reaction batch using $15 \%(\mathrm{w} / \mathrm{V})$ of corn starch, $0.1 \%(\mathrm{~V} / \mathrm{V})$ of Toruzyme ${ }^{\circledR}$ enzyme and $\mathrm{pH} 6$ at $65{ }^{\circ} \mathrm{C}$, and obtained $32.92 \mathrm{mmol} \mathrm{L}^{-1}$ of $\alpha-\mathrm{CD} ; 21.96 \mathrm{mmol} \mathrm{L}^{-1}$ of $\beta-\mathrm{CD}$ and $3.98 \mathrm{mmol} \mathrm{L}^{-1}$ of $\gamma$-CD. Fenelon et al. (2015) obtained, with eight batches of $12 \mathrm{~h}, 9.12 \mathrm{mmol} \mathrm{L}^{-1}$ in the first batch and $7.92 \mathrm{mmol} \mathrm{L}^{-1}$ of $\beta-\mathrm{CD}$ in the last batch, with semipurified enzyme of Bacillus fusmus strain 37, 5\% (w/V) of corn starch and $10 \%(\mathrm{~V} / \mathrm{V})$ ethanol. Other authors that used the ultrafiltration system to separate the CDs also obtained promising results, producing CDs in repetitive or continuous batches (Schöffer et al., 2013; Sakinah et al., 2014; Rakmai, Cheirsilp, 2016; Fenelon et al., 2018).

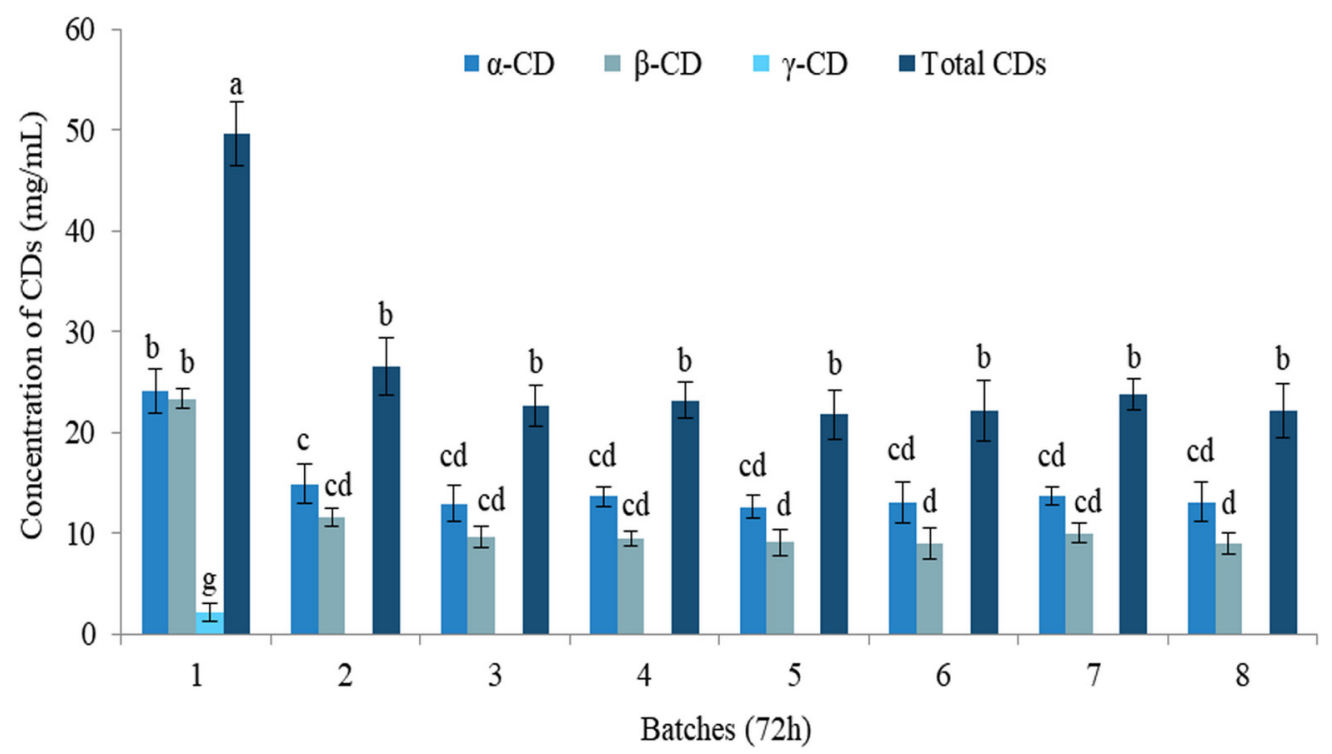

FIGURE 6 - Production of cyclodextrins in repetitive batches and ultrafiltration using $10 \%$ cassava starch with $10 \%$ ethanol and commercial enzyme $0.02 \%(\mathrm{~V} / \mathrm{V})$. Chromatographic analysis. 
Although the production of $\alpha-\mathrm{CD}$ was reduced by half in the third batch and the production of $\beta-C D$ by the same rate in the second batch, after completing all the batches it was found that the enzyme was highly resistant to denaturation, as it maintained the same activity for another six batch repetitions of $72 \mathrm{~h}$.

\section{Crystallization and purification of $\beta-C D$}

Ultrafiltered samples were obtained from each cycle after eight consecutive cycles of $72 \mathrm{~h}$ followed by ultrafiltration. These samples were pooled and subjected to the crystallization process. A quantity of $2.1 \mathrm{~g}$ of precipitate was obtained from crystallization, which was resuspended and analyzed by chromatography, reaching $67.6 \%$ purity of $\beta-\mathrm{CD}$, or $1.42 \mathrm{~g}$ of moisturefree $\beta-C D$. The purity of $\beta-C D$ may have been affected by the presence of other oligosaccharides of low molar mass which passed through the ultrafiltration process, forming a precipitate with the same. The yield and purity of $\beta$-CD obtained with repetitive batches followed by ultrafiltration can be considered satisfactory. Moriwaki et al. (2014) used the CGTase of B. firmus strain 37 and $B$. sphaericus strain 41 immobilized on vegetable sponge and corn starch as a substrate for $72 \mathrm{~h}$, and obtained $64 \%$ crystallized $\beta-C D$ in both strains.

Lyophilization was carried out with the supernatant remaining from the crystallization process. This supernatant, which contained mainly $\alpha-C D$, resulted in a powder of $11.11 \mathrm{~g}$, free of moisture. The powder was resuspended and analyzed by chromatography, from which approximately $35 \%$ of $\alpha-C D$ and $15 \%$ of $\beta-C D$ were obtained.

\section{Separation of CDs by 1 kDa membrane ultrafiltration, crystallization and recrystallization}

Of the different molecular weights of the CDs and using a $1 \mathrm{kDa}$ membrane, almost all the $\alpha-\mathrm{CD}$ expected in the ultrafiltrate was lyophilized after the first $10 \mathrm{kDa}$ membrane ultrafiltration. Similarly, a high predominance of $\beta$-CD together with $\gamma-C D$ in the membrane-retained contents was expected and was subsequently crystallized. However, it was observed that of the total CDs in the ultrafiltrate, $58 \%$ corresponded to $\alpha-C D$ and $42 \%$ to $\beta-C D$, while the presence of $\gamma-C D$ was not detected. In the membrane-retained content, $42 \%$ of $\alpha-C D, 44 \%$ of $\beta-C D$ and $14 \%$ of $\gamma-C D$ were obtained. These results demonstrated the low efficiency of the $1 \mathrm{kDa}$ membrane for the separation of $\alpha$ - and $\beta-C D$, but confirmed its ability to retain the $\gamma-C D$ in its entirety.The crystallization of the membrane-retained content increased the purity of $\beta-\mathrm{CD}$ from $67.6 \%$, the result described above, to $72 \%$. Recrystallization of the same sample resulted in only a small increase in purity, reaching $74 \%$, which does not justify the recrystallization process used.

\section{CONCLUSION}

The production of CDs in repetitive batches using low-concentration thermostable commercial CGTase is of industrial interest due to its economic viability. The ultrafiltration system used allows the continuous production of CDs, removing the inhibitory products from the medium, and enables the reuseof the same enzyme in several consecutive batchings over a prolonged period.

Studies involving the use of cassava starch substrate in the production of CDs are significant as this substrate is easily accessible and inexpensive, allowing the commercial use of CDs at a satisfactory price. Ethanol, as well as helping to increase the production yield of the CDs and prevent microbial contaminations is a nontoxic solvent that can be recovered and reused for other subsequent processes. A simple crystallization process was necessary to obtain a high yield of $\beta-C D$ with almost $70 \%$ purity, and alsoproduced the other CDs.

\section{REFERENCES}

Abdel-Naby MA, Fouada A, Reyadb RM. Catalytic and thermodynamic properties of immobilized Bacillus amyloliquefaciens cyclodextrin glucosyltransferase on different carriers. J Mol Catal B: Enzym. 2015;116:140-147.

ANVISA - Agência Nacional de Vigilância Sanitária. (Brasil). Farmacopéia Brasileira, Brasília, 2010. Avaiable from: file:///C:/Users/Usuário/Documents/Farmacopéia\%20 Brasileira/Farmacopéia\%20Brasileira\%205\%20ed\%20 Volume\%201.pdf

Bonilha PRM, Menocci V, Goulart AJ, Polizeli MLTM, Monti R. Cyclodextrin glycosyltransferase from bacillus licheniformis: optimization of production and its properties. Braz J Microbiol. 2006;37(3):317-323.

Bradford M.M.Arapidand sensitivemethod for the quantitation of microgram quantities of protein utilizing the principle of protein-dye binding. Anal Biochem.1976;72:248-254. 
Caiming L, Qi X, Zhengbiao G, Shuangdi C, Zhaofeng L. Cyclodextrin glycosyltransferase variants experience different modes of product inhibition. J Mol Catal B: Enzym. 2016;133:203-210.

Calsavara LPV, Cunha A RD, Balbino TA, Zanin GM, Moraes FF. Production of Cyclodextrins from Cornstarch Granules in a Sequential Batch Mode and in the Presence of Ethanol. Appl Biochem Biotechnol. 2011;165(7-8):1485-1493.

Centro de estudos avançados em economia aplicada-ESALQ/ USP.[citad 2018 Oct26]. Available from:https://www.cepea. esalq.usp.br/br/indicador/mandioca.aspx.

Dixon M, Webb EC. $3^{\text {a }}$ ed. Enzymes. London; 1979.

Dubois M, Gilles KA, Hamilton JK, Rebers PA, Smith F. Colorimetric method for determination of sugars and related substances. Anal Chem.1956;28(3):350-356.

Fenelon VC, Aguiar MFA, Miyoshi JH, Martinez CO, Matioli G. Ultrafiltration system for cyclodextrin production in repetitive batches by CGTase from Bacillus firmus strain 37 . Bioprocess Biosyst Eng. 2015;38(7):1291-1301.

Fenelon VC, Miyoshi JH, Mangolim CS, Noce AS, Koga LN, Matioli G. Different strategies for cyclodextrin production: Ultrafiltration systems, CGTase immobilization and use of a complexing agent. Carbohydr Polym. 2018;192:19-27.

Gomes E, Guez MAU, Martin N, Silva R. Enzimas termoestáveis: fontes, produção e aplicação industrial. Quim. Nova. 2007;30(1):136-145.

Grüll LD, StifterKU. Process for the production of cyclodextrins. Patent No. 6.235.505 B1.SidZucker Aktiengesellschaft, Mannheim/Ochsenfurt (DE); 2001.

Han R, Li J, Shin H, Chen RR, Du G, Liu L, Chen J. Recent advances in discovery, heterologous expression, and molecular engineering of cyclodextrin glycosyltransferase for versatile applications. Biotechnol Adv. 2014;32(2):415-428.

Ibrahim ASS, Al-Salamah AA, El- Tayeb MA, El-Badawi YB, Antranikian GA. Novel cyclodextrin glycosyltransferase from alkaliphilic Amphibacillus sp. NPST-10: purification and properties. Int J Mol Sci. 2012;13(8):10505-10522.

Kim TJ, Kim BC, Lee HS. Production of cyclodextrins using raw corn starch without a pretreatment. Enzyme Microb Technol. 1997;20(7):506-509.

Kurkov SV, Loftsson T. Cyclodextrins. Int J Pharm. 2013;453(1):167-180.
Matioli G, Zanin G M, Moraes F F. Characterization of cyclodextrin glicosiltransferase from Bacillus firmus strain $\mathrm{n}^{\circ}$ 37. Appl Biochem Biotechnol. 2001;91-93(1):643-654.

Matte MR, Benvenutti EV, Schöffer JN, Ayub MAZ, Hertz PF. Characterization of cyclodextrin glycosyltransferase immobilized on silica microspheres via aminopropyltrimethoxysilane as a "spacer arm". J Mol Catal B: Enzym. 2012;78:51-56.

Mattsson P, Korpela T, Paavilainen S, Mäkellä M. Enhanced conversion of starch to cyclodextrins in ethanolic solutions by Bacillus circulans alkalophilus cyclomaltodextrin glucanotransferase. Appl Biochem Biotechnol. 1991;30(1): 17-28.

Moriwaki C, Costa GL, Pazzetto R, Zanin GM, Moraes FF, Portilho M, Matioli G. Production and characterization of a new cyclodextrin glycosyltransferase from Bacillus firmus isolated from Brazilian soil. Process Biochem. 2007;42: 1384-1390.

Moriwaki C, Mangolim CS, Ruiz GB, Morais GR, Baesso ML, Matioli G. Biosynthesis of CGTase by immobilized alkalophilic bacilli and crystallization of beta-cyclodextrin: Effective techniques to investigate cell immobilization and the production of cyclodextrins. BiochemEng J. 2014;83: 22-32.

Moriwaki C, Mazzer C, Pazzetto R, Matioli G. Produção, purificação e aumento da performance de ciclodextrina glicosiltransferases para produção de ciclodextrinas. Quim Nova. 2009;32(9):2360-2366.

Muria SR, Cheirsilp B, Kitcha S. Effect of substrate concentration and temperature on the kinetics and thermal stability of cyclodextrin glycosyltransferase for the production of $\beta$-cyclodextrin: Experimental results vs. mathematical model. Process Biochem. 2011;46(7):1399-1404.

Norman BE, Jorgensen ST. Thermoanaerobacter sp CGTase: its properties and applications. Denpun Kagaku. 1992;39: 101-108.

Pinheiro K H, Nascimento L B, Fenelon V C, Barão C E, Matioli G, Moraes F F. Mathematical modelling and kinetic study for CD production catalysed by Toruzyme and CGTase from Bacillus firmus strain 37. Bioprocess Biosyst Eng. 2017;40:1305-1316.

Pishtiyski I, Zhekova B. Effect of different substrates and their preliminary treatment on cyclodextrin production. World J Microbiol Biotechnol. 2006;22:109-114.

Rakmai J, Cheirsilp B, Prasertsan P. Enhanced thermal stability of cyclodextrin glycosyltransferase in alginate- 
gelatin mixed gel beads and the application for $\beta$-cyclodextrin production. Biocatal Agric Biotechnol. 2015;4(4):717-726.

Rakmai J, Cheirsilp B. Continuous production of $\beta$-cyclodextrin by cyclodextrin glycosyltransferase immobilized in mixed gel beads: Comparative study in continuous stirred tank reactor and packed bed reactor. Biochem Eng J. 2016;105(Part A):107-113.

Sakinah MMA, Ismail AF, Ilias RM, Zularisam AW, Hassan $\mathrm{O}$, Matsuura T. Effect of substrate and enzyme concentration on cyclodextrin production in a hollow fibre membrane reactor system. Sep Purif Technol. 2014;124:61-67.

Schöffer JN, Klein MP, Roqdrigues RC, Hertz PF. Continuous production of $\beta$-cyclodextrin from starch by highly stable cyclodextrin glycosyltransferase immobilized on chitosan. Carbohydr Polym. 2013;98(2):1311-1316.

SEAB - Secretaria de Estado da Agricultura e do Abastecimento.[citad 2018 Oct 26].Available from: http://www.agricultura.pr.gov.br/arquivos/File/deral/ Prognosticos/2018/Mandioca_2017_18.pdf

Segel IH. Enzyme Kinetics. A Wiley-Interscience Publication, New York. 1975.
Slomińska L, Szostek A, Grześkowiak A. Studies on enzymatic continuous production of cyclodextrins in an ultrafiltration membrane bioreactor. Carbohydr Polim. 2002;50(4):423-428.

Szejtli J. Introduction and general overview of cyclodextrin chemistry. Chem Rev. 1998;98(5):1743-1753.

Tardioli PW, Zanin GM, Moraes FF. Characterization of Thermoanaerobacter cyclomaltodextrin glucanotransferase immobilized on glyoxil-agarose. Enzyme Microb Technol. 2006;39(6):1270-1278.

Tiwari G, Tiwari R, Raia K. Cyclodextrins in delivery systems: Applications. J Pharm Bioallied Sci. 2010;2(2): 72-79.

Unsworth LD, Oost JV, Koutsopoulos S. Hyperthermophilic enzymes - stability, activity and implementation strategies for high temperature applications. FEBS J. 2007;274(16): 4044-4056.

Zhou W, Feng B, Huang H, Qin Y, Wang Y, Kang L, Zhao Y, Wang X, Cai Y, Tan D, Ma B. Enzymatic synthesis of $\alpha$-glucosyl-timosaponin BII catalyzed by the extremely thermophilic enzyme: Toruzyme 3.0L. Carbohydr Res. 2010;345(12):1752-1759.

Received for publication on $03^{\text {rd }}$ December 2018 Accepted for publication on $30^{\text {th }}$ April 2019 